\title{
Pengembangan Skala Efikasi Diri untuk Kesehatan Kerja (SEDKK): Studi Pendahuluan
}

\section{Retno Widowati}

Program Studi Magister Biologi, Sekolah Pascasarjana, Universitas Nasional, Jakarta Fakultas Ilmu Kesehatan, Universitas Nasional, Jakarta

\section{Albiruni Raushanfikri}

Business Psychology, Bonn-Rhein-Sieg University of Applied Sciences, Sankt Augustin, Jerman

Abstrak. Studi ini bertujuan untuk memvalidasi perangkat penilaian efikasi diri yang berkaitan dengan kesehatan kerja yang dikembangkan pada tahap studi pendahuluan. Skala Efikasi Diri untuk Kesehatan Kerja (SEDKK) berlandaskan konsep efikasi diri pada teori kognitif sosial yang mengukur empat faktor yang berpengaruh pada kesehatan setiap individu yang bekerja, seperti: perilaku makan dan minum, tidur, keamanan dan kesehatan kerja, serta kegiatan pemulihan dari stres bekerja. Hasil analisis faktor eksploratori menunjukan bahwa ada empat faktor yang terefleksikan dari butir-butir SEDKK. Validitas konstruk SEDKK dapat dibuktikan dengan korelasi positif antara SEDKK dan skala Efikasi Diri Umum yang sangat signifikan. Pengujian validitas kriteria dapat ditelusuri melalui efek SEDKK terhadap kondisi kesehatan umum, kepuasan akan kesehatan pribadi, keseimbangan kehidupan kerja/KKK (work life balance), perilaku sehat, dan perilaku berisiko. Namun demikian, asumsi mengenai reliabilitas tes berulang (test-retest) pada penelitian ini ditolak. Implikasi dan saran-saran untuk penelitian selanjutnya didiskusikan pada artikel ini.

Kata Kunci: analisis faktor eksploratori, diagnostik, efikasi diri, kesehatan kerja, perilaku hidup sehat

\section{The Development of Self Efficacy Scale for Occupational Health Behavior: An Initial Study}

Abstract. This study is an attempt to validate a tool for measuring the self-efficacy for occupational health behavior on the pilot study level. The scale of self-efficacy for occupational health behavior (SEDKK) based on the concept of self-efficacy inside the theory of social cognitive, which integrates itself into four determinants regarding occupational health, such as: dietary behavior, sleeping behavior, occupational safety and health, as well as recovery activities after work. The explorative factor analysis show that there are four occured dimensions of SEDKK. Construct validity was indicated by the positive correlation between SEDKK and General Self-Efficacy scale. The criterion validity could be tracked by the effects of SEDKK on general health condition, health satisfaction, work life balance, healthy behaviors, and risk behaviors. However, SEDKK could not show any test-retest reliability. The implications and suggestions for further researches are discussed in this article.

Keywords: diagnostic, explorative factor analysis, healthy behavior, occupational health, selfefficacy

Kopartisipansi: Albiruni Raushanfikri. Email: albiruni.raushanfikri@smail.wir.h-brs.de 
Perkembangan model-model psikologi kesehatan yang pesat di dasawarsa akhir ini mendorong pengembangan sebuah alat ukur efikasi diri (self-efficacy) yang mutakhir dan diperbarui dalam hal kesehatan individu yang bekerja. Efikasi atau keyakinan diri sudah banyak diteliti oleh beragam disiplin ilmu pengetahuan sosial dan untuk menjelaskan hubungannya dengan aspek-aspek perilaku manusia (Hou et al, 2019; Purnomo \& Lestari, 2010; Saraswati \& Prihatsanti, 2017). Penggunaan skala pengukuran efikasi diri biasanya mengacu kepada General SelfEfficacy (GSE) oleh Born et al (1995) atau SelfEfficacy Scale oleh Sherer et al. (1982). Dalam aplikasinya, efikasi diri adalah salah satu prediktor yang kuat untuk memprediksi perilaku individu di waktu mendatang (Bandura, 2004; Vollmann \& Weber, 2011).

Kesehatan kerja karyawan merupakan hal penting untuk dievaluasi, karena memegang peranan penting dalam menjaga kinerja karyawan yang memiliki keterkaitan dengan kelangsungan hidup sebuah perusahaan. Huettermann dan Bruch (2019) melaporkan bahwa hubungan positif antara manajemen sumber daya manusia yang berorientasikan pada kesehatan kerja karyawannya dan kinerja perusahaan yang termediasi melalui pola pikir positif karyawan dan keterikatan kolektif pada setiap organisasi. Conradie et al. (2016) juga melaporkan tentang efek langsung dari program kesehatan perusahaan terhadap manfaat keuangan perusahaan di Afrika Selatan.
Menjaga kesehatan kerja karyawan dapat dilakukan salah satunya dengan mengaktifkan rambu-rambu peringatan seperti pemeriksaan kesehatan berkala yang sudah banyak diterapkan oleh perusahaan-perusahaan. Dengan adanya pemeriksaan tersebut, maka hal-hal berisiko yang mengancam kesehatan karyawan dapat terlacak, sehingga langkahlangkah intervensi dapat diambil sesegera mungkin demi menghindari kejadian yang tidak diinginkan, seperti kecelakaan kerja karena hilang konsentrasi, kelelahan kerja (burnout), depresi, dan lain sebagainya. Efikasi diri sebagai salah satu rambu dalam memperkirakan perilaku kerja yang mendukung kesehatan karyawan. Hal tersebut menjadi motivasi kuat dalam mengembangkan Skala Efikasi Diri untuk Kesehatan Kerja (SEDKK). Skala Efikasi Diri untuk Kesehatan Kerja diharapkan tidak hanya dapat memberikan sinyal kepada setiap individu yang bekerja akan efikasi dirinya, dalam rangka memprediksi perilakunya yang dapat mendukung keselamatan dan kesehatan kerja. Selanjutnya, hasil pengukuran skala tersebut dapat mendeteksi lebih awal perilaku karyawan yang mungkin berisiko bagi kondisi keselamatan dan kesehatan kerja.

Satu metode yang dinilai relevan dalam pengembangan SEDKK adalah memberikan preferensi waktu pada pertanyaannya, seperti tiga bulan terakhir. Preferensi waktu memberikan pembatas imajiner yang membantu partisipan dalam mengingat 
kejadian, sikap, dan perilakunya di ruang waktu yang diberikan itu. Preferensi waktu juga dinilai penting untuk mengantisipasi munculnya distorsi persepsi, bias, atau generalisasi kejadian. Contohnya jika ada sebuah pernyataan seperti, "Saya tidak mempunyai kesulitan untuk melaksanakan niat dan tujuan saya", maka besar kemungkinannya jika partisipan dapat merespon pernyataan ini dengan mengingat kembali kejadian-kejadian terlepas dari batas waktu kapan partisipan pernah memiliki niat atau tujuan tersebut. Gejala bias juga dapat muncul karena mungkin partisipan baru dipromosikan ke jabatan yang lebih tinggi sehingga partisipan menyetujui pernyataan (Chang et al., 2018).

Namun demikian, jika seorang partisipan dikonfrontasikan dengan contoh pernyataan "Saya tidak mempunyai kesulitan untuk melaksanakan niat dan tujuan saya selama tiga bulan terakhir ini", maka disini partisipan akan dihadapkan pada kondisi efikasi diri yang lebih konkrit selama tiga bulan terakhir. Partisipan dapat merefleksikan keadaan, sikap serta tingkah lakunya lebih terperinci. Hal ini dinilai penting mengingat perubahan sikap atau perilaku akan menjadi lebih mudah untuk diintervensi jika sikap atau perilaku itu detail (Chapman, 2019; Korinek et al., 2018). Hal inilah yang kemudian diintegrasikan ke dalam SEDKK dalam prosedur penjawabannya. Di sisi lain, hal ini juga dapat memudahkan para praktisi kesehatan kerja dalam mengakses fenomena- fenomena kesehatan kerja lebih mendetail. Contohnya mereka dapat lebih mudah untuk memonitor perkembangan pola hidup dan kondisi kejiwaan seseorang yang sedang dihadapkan dengan tindakan pencegahan tertentu dari waktu ke waktu, seperti terapi bebas rokok, dan sebagainya.

Karena harapan akan pemanfaatan SEDKK yang fleksibel dan pragmatis dalam mengukur efikasi diri dalam menjalankan perilaku kerja yang sehat, maka penggunaan satu landasan teori tidaklah cukup untuk menopang konstruksi SEDKK. Oleh karena itu, Teori Efikasi Diri (Bandura, 1997), Teori Kognitif Sosial (Bandura, 2004), dan Keselamatan dan Kesehatan Kerja (ILO, 2013) menjadi landasan utama dalam pengembangan SEDKK. Dengan demikian, pengintegrasian beberapa konsep, model, paradigma, dan teori memberikan warna tersendiri bagaimana SEDKK melihat efikasi diri seseorang yang berhubungan dengan perilakunya yang terkait dengan kesehatannya. Dengan kata lain, efikasi diri dalam konteks SEDKK meliputi tiga segi kesehatan: (a) kesehatan jasmani, seperti pola makan dan minum, pola tidur, dan olahraga; (b) kesehatan kejiwaan, seperti pengaturan atas kebahagian sendiri atau hubungan sosial; dan (c) kesehatan di tempat kerja, seperti kesehatan dan keselamatan kerja.

Merujuk kepada Bandura (1994), efikasi diri disamakan dengan keyakinan atau percaya atas kemampuan diri seseorang untuk meraih tujuan di masa yang akan datang. Keyakinan ini 
menjadikan penentu bagaimana seseorang berpikir dan memotivasi dirinya sendiri untuk melakukan aksi guna meraih tujuan di waktu sebelumnya. Jadi, semakin besar efikasi diri, semakin besar pula kemungkinan seseorang meraih tujuan. Hal ini dapat dibuktikan secara empiris oleh Rovniak et al. (2002) yang menemukan pengaruh yang besar dari efikasi diri terhadap aktivitas fisik, seperti pergi ke tempat pusat kebugaran, bersepeda, atau bowling.

Efikasi diri menurut Branden (2017) adalah perasaan dan keyakinan seseorang akan kekuatan dan kompetensi yang dimiliki. Individu yang memiliki efikasi diri percaya bahwa dengan segala kemampuan yang ia miliki, ia yakin untuk dapat meraih tujuan yang ia tuju. Individu tersebut biasanya tahu bagaimana ia dapat menghadapi persoalan yang menghadangnya dalam proses pencapaian tujuannya tersebut. Selain keyakinan, efikasi diri juga didefinisikan sebagai ekspektasi, bahwa kerja keras seseorang akan selalu diiringi keberhasilan (Branden, 2017).

Seseorang dengan efikasi diri memiliki pengalaman-pengalaman akan keberhasilannya dan ia menggunakan pengalaman tersebut dalam menilai kemampuannya untuk meraih tujuannya tersebut. Semakin banyak seorang individu menggunakan beragam cara atau kompetensi dalam menyelesaikan masalah, maka semakin beragam pula individu tersebut memiliki cara untuk menyelesaikan masalah di masa yang akan datang. Di sinilah salah satu ciri dari efikasi diri, bahwa efikasi diri itu adalah kompetensi yang sebenarnya masih di bawah kontrol manusia (Branden, 2017). Branden (2017) juga menjelaskan bahwa efikasi diri bukanlah sebuah keyakinan bahwa seseorang tidak dapat salah atau keliru, namun keyakinan bahwa seseorang bisa mengkoreksi kesalahan atau kekeliruannya. Efikasi diri juga bukan sebuah ketentuan bahwa setiap manusia bisa melampaui tantangan, namun dengan adanya tantangan yang dihadapi individu, ia dapat mengalami, belajar, dan berkembang terhadap potensi yang sebelumnya terpendam.

Hubungan positif antara efikasi diri dengan fenomena psikologis manusia seperti kesehatan, pekerjaan, kehidupan sosial, dan lain sebagainya sudah banyak mendapatkan perhatian dari kalangan peneliti, praktisi, dan di berbagai bidang. Khususnya dalam bidang Psikologi Industri dan Organisasi, Purnomo dan Lestari (2010) membuktikan bahwa efikasi diri memiliki efek positif terhadap persepsi kinerja usaha skala kecil dan menengah. Efikasi diri juga dilaporkan dapat memprediksi motivasi dan kinerja dari karyawan (Cherian \& Jacob, 2013), pengambilan keputusan karier (Betz et al., 1996), perkembangan karier (Dimotakis et al., 2017), dan kepuasan kerja (Klassen \& Chiu, 2010). Efikasi diri juga memainkan peran penting terhadap kesehatan manusia, seperti perilaku hidup sehat (Brouwer-Goossensen et al, 2018; Jankowska 
et al., 2017) dan pemulihan setelah mengalami stres di tempat kerja (Park \& Kim, 2018).

Bandura (1982) menjelaskan bahwa efikasi diri yang tinggi memprediksi keberhasilan seseorang dalam meraih tujuannya. Meskipun demikian, efikasi diri tidak hanya berorientasi pada kejadian di masa datang, efikasi diri juga ditandai dengan operasionalisasi atau pengejawantahan dari tujuan pada cara-cara untuk meraih tujuan tersebut (Feng et al., 2015). Mengetahui cara dan strategi bagaimana individu dapat meraih kesuksesan selain dengan meniru dalam konteks psikologi pembelajaran -seperti menjalankan tips-tips untuk membaca cepat-, pengalaman atas kesuksesan di masa lalu menjadi patokan kuat untuk membangun efikasi diri (Malanchini et al., 2018; Raufelder \& Ringeisen, 2016). Dalam kehidupan seharihari, manusia tentunya memiliki beragam pondasi untuk memperkirakan kemungkinan untuk meraih tujuan tersebut (Brusso et al., 2012; Meissel \& Rubie-Davies, 2016). Dengan kata lain, determinan yang paling menentukan tingkat efikasi diri pada seseorang adalah pengalaman di mana individu tersebut berhasil meraih hal yang ia cita-citakan tanpa membedakan seberapa besar atau kecilnya keberhasilan tersebut (Bandura, 2004; Branden, 2017; Sonnentag et al., 2017).

Selain menjadi prediktor yang kuat untuk memprediksi perilaku sehat pada teori kognitif sosial, efikasi diri juga diintegrasikan ke dalam model Health Action Process Approach
(HAPA) atau model pendekatan proses aksi kesehatan (Schwarzer, 2016; Zhang et al., 2019). Pada model ini, efikasi diri berperan penting dalam proses penentuan tujuan, perencanaan, dan perilaku. Dengan kata lain, efikasi diri tidak hanya menjadi salah satu faktor penentu dalam fase motivasi, tetapi juga dalam fase pelaksanaan aksi (Lippke \& Renneberg, 2006). Schwarzer (2016) membagi efikasi diri kepada tiga jenis, yaitu: (a) efikasi diri di tingkat aksi (action self-efficacy), (b) efikasi diri di tingkat pemeliharaan (maintenance self-efficacy), dan (c) efikasi diri di tingkat pemulihan (recovery self-efficacy). Efikasi diri di tingkat aksi adalah efikasi diri yang pertama kali muncul pada tahap proses pembentukan motivasi yang terjadi sebelum fase pelaksanaan aksi atau perilaku dijalankan. Sedangkan efikasi diri di tingkat pemeliharaan mengambil alih peran ketika proses pelaksanaan aksi berlangsung. Seseorang yang memiliki efikasi diri yang tinggi akan lebih menunjukan daya juang yang lebih daripada seseorang dengan efikasi diri yang rendah. Sedangkan efikasi diri di tingkat pemulihan merupakan efikasi diri yang memengaruhi seseorang untuk kembali mengelola dirinya setelah mengalami kegagalan dalam melaksanakan aksi tersebut. Dalam penelitian ini, SEDKK menekankan efikasi diri di tingkat aksi dalam mengembangkan butir-butirnya.

Dalam konteks psikologi klinis, efikasi diri memiliki hubungan negatif terhadap gejala-gejala depresi (Greenfield et al., 2012; 
Maciejewski et al., 2000). Hasil riset-riset tersebut juga menerangkan bahwa efikasi diri dari individu-individu yang pernah mengalami depresi dapat menurun jika berhadapan kembali dengan pengalaman hidup negatif. Rendahnya efikasi diri juga berasosiasi dengan tingginya tekanan darah dan hilangnya kontrol diri (Schaubroeck \& Merritt, 1997), penyalahgunaan psikotropika (Perkonigg et al, 2008), dan ketakutan akan masa depan (Feng et al., 2015).

Efikasi diri juga merupakan kondisi kejiwaan yang tidak statis. Derajatnya dapat dipengaruhi dari faktor baik dari dalam atau luar seseorang. Salah satu cara yang paling mudah untuk meningkatkan efikasi diri adalah mengingat pengalaman keberhasilan, seperti yang dikemukakan oleh Bandura (2004) atau Branden (2017). Selain itu, penyuluhan atau workshop dilaporkan dapat meningkatkan efikasi diri. Coogle et al. (2016) menemukan peningkatan efikasi diri yang sangat signifikan setelah peserta mengikuti program pengembangan lintas bidang di bidang geriatri. Dalam program ini peserta diberikan penyuluhan tentang peningkatan efikasi diri yang berhubungan dengan promosi kesehatan, keamanan kerja, evaluasi, dan diagnosis bagi pasien-pasien yang berusia lanjut. Dukungan dari lingkungan sosial juga dapat memengaruhi peningkatan efikasi diri. Hou et al. (2019) membuktikan tentang efek dari dukungan sosial yang memengaruhi hubungan antara efikasi diri pengambilan keputusan dan adaptasi karier.
Perilaku istirahat yang disasar oleh SEDKK adalah perilaku tidur. Barnes dan Drake (2015) menekankan bahwa perilaku tidur menjadi faktor yang memengaruhi kualitas hasil berpikir, kesehatan mental dan fisik, serta perilaku dan keselamatan kerja. Rendahnya kualitas tidur seseorang dilaporkan dengan tingginya risiko seseorang untuk mengalami obesitas (Taheri et al., 2004), ketidakefektifan seseorang dalam mengambil keputusan (Killgore et al., 2006), rendahnya kualitas hasil kerja (Drake et al., 2001), dan kecenderungan untuk berperilaku tidak etis (Barnes et al., 2011). Park dan Sprung (2015) menjelaskan hubungan antara efikasi diri dan perilaku tidur pada mahasiswa yang melakukan kerja sampingan. Sebagai contoh, riset tersebut menemukan bahwa mahasiswa dengan efikasi diri yang rendah lebih rentan untuk mengalami gangguan tidur dan kelelahan di akhir pekan. Tiga butir SEDKK meliputi pernyataanpernyataan yang berhubungan dengan penilaian subjektif akan tidur sehat, tidur nyenyak, dan waktu tidur antara enam hingga delapan jam untuk manusia dewasa (Goodhines et al., 2019).

Keselamatan dan Kesehatan Kerja (K3) menjadi salah satu titik berat yang diukur di dalam SEDKK karena konsep tersebut melingkupi garis besar penanggulangan risiko kecelakaan dan gangguan kesehatan yang terjadi di lingkungan kerja seseorang. Merujuk pada pedoman pelatihan untuk manajer dan pekerja, International Labour Organization (ILO, 2013) 
mengategorikan potensi bahaya dan risiko di tempat kerja ke dalam empat dimensi secara terperinci, seperti kategori A untuk potensi bahaya yang berdampak risiko jangka panjang pada kesehatan dengan pembabaran bahaya faktor kimia, fisika, biologi, hingga ergonomi dan pengaturan kerja. Namun dalam pengembangan SEDKK -sesuai dengan tujuannya yang bersifat singkat- butir-butir yang dikembangkan bersifat umum. Terlebih, jika Pemerintah Republik Indonesia dengan Undang-Undang No. 1/1970 dan No. 23/1992 memberikan tolak ukur bagi organisasi dan perusahaan untuk mematuhi rambu-rambu tersebut. Sebaliknya, butir-butir SEDKK mengukur efikasi diri yang mengacu kepada K3 melalui kacamata subjektif pengisinya. Bagaimanapun juga, pribadi setiap orang yang bekerja ikut bertanggung jawab terhadap K3 pribadi. Dari sisi kepribadian contohnya, Beus et al (2015) menemukan dalam metaanalisisnya bahwa keramahan (agreeableness) dan ketekunan (conscientiousness) memiliki korelasi negatif dengan perilaku tidak aman. Kembali kepada pokok permasalahan tentang hubungan efikasi diri dan perilaku aman serta sehat dari pekerja, Richard et al. (2011) dalam studinya dapat menjelaskan efikasi diri sebagai determinan yang penting dalam perkembangan sakit punggung dari pekerja. Efikasi diri untuk K3 dioperasionalisasikan dengan menanyakan penilaian subjektif partisipan terhadap perilaku di tempat kerja dan kondisi kesehatan setelah bekerja.
Aktivitas di waktu luang menjadi salah satu faktor penentu dalam menjaga kesehatan manusia. Merujuk pada konsep pemulihan dari stres pekerjaan Craig (1992), aktivitas di waktu luang dapat memulihkan kondisi mental yang digunakan ketika bekerja jika aktivitas tersebut bisa mengalihkan perhatian dan ingatan seseorang untuk fokus pada kegiatan di waktu bebasnya. Adapun aktivitas-aktivitas di luar pekerjaan yang menjadi faktor penentu untuk terbentuknya kesehatan mental yang menjadi fokus SEDKK adalah kegiatan fisik, hobi, dan aktivitas sosial. Kegiatan fisik seperti olahraga diberitakan dapat memulihkan keseimbangan mental setelah bekerja (2017). Berkaitan dengan hobi atau kegemaran, Van Den Berg dan Custers (2010) menemukan efek dari berkebun selama 30 menit dapat menurunkan kadar kortisol dan meningkatkan kondisi emosi yang positif.

Kegiatan sosial juga mendapat sorotan dalam penelitian di bidang pemulihan kondisi kesehatan pekerja. Csikszentmihalyi (2008) menerangkan bahwa seseorang dapat memulihkan kondisi mental dan emosinya dengan melakukan kegiatan sosial seperti berjumpa dengan teman-temannya. Ketika orang tersebut dapat tampil autentik dan hubungan pertemanannya menerima individu tersebut apa adanya, maka kebutuhan akan hubungan antar manusia dapat terpenuhi. Pada titik itulah, orang tersebut mengalami keterpenuhan kebutuhan sosial, penerimaan dari konstelasi sosial, dan peningkatan estimasi 
dirinya (Grawe et al, 1994). Dengan demikian, kesehatan mental seseorang akan terjaga jika orang tersebut bisa menyeimbangkan pemulihan dan pengeksploitasi sumber daya mental (Bakker \& Demerouti, 2007).

Penelitian ini bertujuan untuk memvalidasi SEDKK. Skala tersebut diintegrasikan dari Teori Efikasi Diri, Teori Kognitif Sosial, dan Keselamatan dan Kesehatan Kerja untuk memperoleh alat ukur efikasi diri yang secara spesifik mengukur perilaku keselamatan kerja yang belum pernah dikonstruksi sebelumnya. Dalam rangka melakukan validasi tersebut, dilakukan beberapa langkah, yaitu melakukan uji validitas konstruk dengan menggunakan uji analisis faktor eksploratori dan uji validitas kriteria.

\section{Metode}

\section{Partisipan}

Partisipan pada pengumpulan data di waktu pertama (T1) untuk penelitian ini terdiri dari 32 mahasiswi (72.7\%) dan 12 mahasiswa (27.3\%) yang telah ikut serta untuk menjadi partisipan dalam proses pengembangan SEDKK pada hari Selasa tanggal 25 Juni 2019. Dua puluh partisipan berusia antara $20-24$ tahun (45.5\%), 16 partisipan berusia $25-29$ tahun (36.4\%), dan tujuh partisipan berusia antara 30 - 34 tahun (15.9\%). Sebanyak 42 partisipan memiliki pendidikan terakhir setingkat diploma atau sederajat (95.5\%) dan dua partisipan berpendidikan terakhir setingkat S1 atau sederajat (4.5\%). Menurut jenis pekerjaan, 19 partisipan adalah mahasiswa/i murni (43.2\%), 16 partisipan bekerja sebagai karyawan swasta (36.4\%), delapan partisipan merupakan aparatur sipil negara (18.2\%), dan satu partisipan (2.3\%) menjawab pilihan dengan "Tidak bekerja/ sedang mencari pekerjaan".

Pada pengumpulan data kedua pada hari Selasa tanggal 30 Juli 2019 (T2) untuk pengujian tes berulang (test-retest), partisipan terdiri dari 27 mahasiswi (71.1\%), 10 mahasiswa (26.3\%), dan satu partisipan (2.6\%) tidak mengidentifikasikan jenis kelaminnya. Dari segi usia, 17 partisipan berusia antara 20 - 24 tahun (44.7\%), 16 partisipan berusia 25 - 29 tahun (42.1\%), dan lima partisipan berusia 30 - 34 tahun (13.2\%). Pada T2, status pendidikan terakhir tidak dipertanyakan kembali mengingat partisipan T1 dan T2 berasal dari populasi yang sama.

\section{Prosedur penelitian}

Pada pengambilan sampel pertama, partisipan diminta untuk mengerjakan tes dengan menggunakan telepon genggam pribadi setelah tautan kuesioner daring disebarkan oleh pimpinan penelitian. Media yang digunakan untuk mengumpulkan sampel adalah soscisurvey.de milik SoSci Survey GmbH. Dalam penelitian ini tidak ada hadiah yang diberikan kepada partisipan. Sebelum pengambilan data, partisipan diminta untuk membaca informasi singkat tentang tujuan penelitian, kesukarelaan, dan penjelasan tentang komitmen dari tim peneliti untuk 
menjaga kerahasiaan dan anonimitas dari partisipan.

Selanjutnya skala yang harus diisi oleh partisipan adalah terdiri dari skala kesehatan umum, kepuasan atas kesehatan pribadi, ekspektasi hasil, dukungan sosial, Efikasi Diri Umum (General Self-Efficacy/GSE), SEDKK, Perilaku kerja dan hidup sehat (PKH-Sehat), Keseimbangan Kehidupan Kerja/KKK (Work Life Balance/WLB), Perilaku kerja dan hidup berisiko (PKH-Risiko), dan pertanyaanpertanyaan demografis. Halaman terakhir ditutup dengan ucapan terima kasih. Pada pengambilan sampel kedua, urutan pertanyaan relatif sama dengan adanya sedikit perubahan seperti penghapusan pertanyaan tentang pekerjaan pada pertanyaan demografis.

\section{Instrumen penelitian}

\section{Skala Efikasi Diri untuk Kesehatan Kerja (SEDKK)}

SEDKK adalah instrumen pengukur efikasi diri untuk penerapan perilaku sehat bagi individu-individu yang memiliki ikatan kerja. Pada pengembangannya, SEDKK terdiri dari 14 pernyataan dengan lima skala Likert mulai dari "sangat tidak setuju" hingga "sangat setuju". Pembatasan rentang waktu antara hari pengisian kuesioner dan tiga bulan terakhir bertujuan untuk memberikan orientasi kepada partisipan dalam menjawab SEDKK. Hal ini juga dilakukan untuk mengantisipasi kemungkinan munculnya distorsi atau bias dalam menjawab SEDKK (Renner et al., 2012).
Komposisi SEDKK sendiri terdiri dari aspek kehidupan manusia yang meliputi: (a) perilaku konsumsi sehat, (b) istirahat, (c) bekerja, dan (d) aktivitas di waktu luang. Alasan pengintegrasian perilaku konsumsi sehat ke dalam SEDKK adalah karena efikasi diri dapat memprediksi perilaku konsumsi (Parkinson et al., 2017). Konsep perilaku konsumsi yang sehat dioperasionalisasikan dengan tiga pernyataan atau butir yang bersangkutan dengan konsumsi atau pola makan dan minum manusia dalam kehidupan sehari-hari. Proses operasionalisasi perilaku konsumsi sehat berorientasi kepada konsep pola makan dan minum yang beragam, bergizi seimbang, dan aman (Pejabat Pelaksana Teknis Kegiatan Peningkatan Penganekaragaman Konsumsi Pangan, 2012; Pemerintah Indonesia, 2009). Pernyataan dari setiap butir SEDKK diformulasikan dengan kalimat langsung dan positif. Parameter SEDKK seperti rata-rata, standar deviasi, atau Alpha Cronbach dapat dilihat pada Tabel 2.

\section{Efikasi Diri Umum (General Self-Efficacy/GSE)}

Efikasi Diri Umum (General SelfEfficacy/GSE) dikembangkan oleh Schwarzer dan Jerusalem (1995) dan terdiri dari 10 butir yang mengukur efikasi diri secara umum. Selain sifatnya yang representatif untuk populasi dunia, General Self-Efficacy juga memiliki terjemahan dalam bahasa Indonesia (Born et al., 1995; Schwarzer et al., 1997). Efikasi Diri Umum diberitakan memiliki 
tingkat validitas yang dapat dipertanggungjawabkan (Scholz et al., 2002). Contoh pernyataan butir dari Efikasi Diri Umum adalah, "Apapun yang terjadi, saya akan siap menanganinya" (Born et al., 1995). Efikasi Diri Umum memiliki format berupa skala Likert berjumlah lima mulai dari "sangat tidak setuju" hingga "sangat setuju". Efikasi Diri Umum digunakan untuk menguji validitas konstruk dari SEDKK pada waktu pengambilan sampel pertama. Alpha Cronbach sebagai parameter konsistensi internal Efikasi Diri Umum pada penelitian ini bernilai 843 .

\section{Kesehatan umum}

Butir yang disusun dari alat ukur yang digunakan untuk mengakses penilaian subjektif dari kesehatan umum partisipan adalah butir nomor B 12 dari Copenhagen Psychosocial Questionnaire (COPSOQ) versi 2018 dalam bahasa Jerman (Kristensen \& Borg, 2000). Butir ini diterjemahkan dari bahasa Jerman ke bahasa Indonesia oleh satu mahasiswa S2 dan satu mahasiswi S1 program studi Psikologi Bisnis di Bonn-Rhein-Sieg University of Applied Sciences di waktu dan tempat yang berbeda. Hasil kedua terjemahan tersebut diakselerasikan dan ditambahkan kalimat "selama tiga bulan terakhir" sebagai preferensi partisipan dalam menjawab kuesioner. Tidak ada pengujian reliabilitas karena skala terdiri dari satu butir. Bunyi butir kesehatan umum adalah, "Menurut Anda, seberapa baik kondisi kesehatan Anda yang
Anda rasakan selama tiga bulan terakhir ini?" Partisipan dapat menjawab pernyataan sesuai dengan kondisi kesehatan mereka dengan penilaian unidimensional yang terbentang dari “0" untuk "sangat buruk" hingga " 11 " untuk "sangat baik". Butir ini digunakan untuk menilai validitas kriteria dari SEDKK, karena efikasi diri memiliki hubungan korelasi positif terhadap kondisi kesehatan manusia (Banik et al., 2018; Zhang et al., 2019). Kesehatan umum memiliki parameter berupa tingkat variasi butir -mengingat terdiri dari satu butirsebesar $3.824(M=8.11 ; S D=1.956)$.

\section{Kepuasan kondisi kesehatan pribadi}

Satu butir ini dibuat dan digunakan untuk memperkirakan tingkat kepuasan partisipan terhadap kondisi kesehatan pribadinya. Pertanyaan tersebut berbunyi "Seberapa puaskah Anda terhadap kondisi kesehatan Anda selama tiga bulan terakhir?" Partisipan dapat menjawab pertanyaan dengan memilih salah satu dari kelima simbol emotikon, mulai dari murung hingga senyum. Butir ini digunakan untuk menilai validitas kriteria dari SEDKK. Lachman dan Weaver (1998) contohnya, menemukan efek moderasi dari -konstruksi yang mirip dengan efikasi diri- yaitu persepsi kontrol diri (sense of control), bahwa manusia dengan pendapatan terbatas namun memiliki persepsi kontrol diri yang tinggi dilaporkan memiliki tingkat kesehatan dan kesejahteraan yang lebih tinggi daripada kelompok dengan pendapatan tinggi 
namun memiliki persepsi kontrol diri yang rendah. Seperti kesehatan umum yang hanya memiliki satu buah butir, parameter yang dapat mencerminkan kepuasan kondisi kesehatan pribadi adalah tingkat variasi butir sebesar .780 dengan rata-rata sebesar 3.68 dan standar deviasi sebesar .883.

\section{Skala pendek Trier untuk mengukur Keseimbangan Kehidupan Kerja/KKK}

Skala ini diadaptasi dari Trierer Kurzskala zur Messung von Work life balance atau Skala Pendek Trier untuk mengukur Keseimbangan Kehidupan Kerja (KKK) yang dikembangkan untuk mengukur kemampuan seseorang dalam menyeimbangankan domain kehidupannya antara pekerjaan dan aktivitas di luar pekerjaan (Syrek et al, 2011). Skala ini memiliki lima butir dengan salah satu butir yang memiliki kode terbalik. Pada studi pendahuluan ini, keseimbangan kehidupan kerja menjadi variabel eksternal untuk menguji validitas konvergen pada SEDKK. Skala ini diterjemahkan dari bahasa Jerman ke dalam Bahasa Indonesia yang dilakukan oleh seorang mahasiswi S1 dan mahasiswa S2 mahasiswa program studi Psikologi Bisnis di Bonn-RheinSieg University of Applied Sciences di tempat dan waktu berbeda. Kedua terjemahan tersebut kemudian dibandingkan kandungannya dan diintegrasikan oleh penulis. Contoh butir dari skala ini seperti, "Saya bisa menyelesaikan pekerjaan dan memenuhi kehidupan pribadi saya dengan baik". Partisipan dapat menjawab keseimbangan kehidupan kerja dengan memilih satu dari lima format jawaban "sangat tidak setuju”, "tidak setuju”, "antara tidak setuju dan setuju", "setuju", atau "sangat setuju". Konsistensi internal untuk keseimbangan kehidupan kerja dengan sampel penelitian meraih Alpha Cronbach sebesar .749.

\section{Perilaku Kerja dan Hidup Sehat (PKH-Sehat)}

Skala ini dikembangkan untuk mengukur validitas kriteria dari SEDKK. Perilaku Kerja dan Hidup Sehat (PKH-Sehat) terdiri dari 14 butir dan memiliki konsistensi internal sebesar .935. Pernyataan-pernyataan dari PKHSehat meliputi perilaku makan dan minum, tidur, keamanan dan kesehatan kerja, serta perilaku di luar waktu kerja. Contoh butir PKHSehat adalah, "Selama tiga bulan terakhir waktu tidur saya berkisar antara 6 - 8 jam". Pada proses menjawab, partisipan dapat memilih satu dari lima tingkat persetujuan sesuai dengan skala Likert.

\section{Perilaku Kerja dan Hidup Berisiko (PKH-Risiko)}

Kebalikan dari PKH-Sehat, Perilaku Kerja dan Hidup Berisiko (PKH-Risiko) memiliki delapan buah butir yang mengandung pertanyaan tentang kebiasan-kebiasan yang dapat membahayakan kondisi kesehatan ketika bekerja dan pada kehidupan sehari-hari, seperti mengabaikan keselamatan dan kesehatan kerja, penyalahgunaan zat-zat psikotropika, dan lain-lain. Instrumen ini memiliki lima pilihan skala Likert yang memudahkan partisipan dalam menjawab sesuai dengan persetujuan subjektif nya. 
Adapun contoh butir dari PKH-Risiko adalah, "Di tiga bulan terakhir ini, rata-rata saya merokok per hari sebanyak:...". Partisipan dapat menjawab satu dari lima skala Likert yang disediakan seperti mulai dari "tidak sama sekali”, “1 - 5 kali”, “6 - 10 kali”, "11 - 15 kali”, sampai dengan "lebih dari 16 kali". PKH-Risiko pada penelitian ini memiliki konsistensi internal dengan Alpha Cronbach sebesar .659.

\section{Metode Analisis Data}

\section{Metode pengujian Analisis Faktor Eksploratori (AFE)}

Validitas konstruksi SEDKK diuji dengan menggunakan Analisis Faktor Eksploratori (AFE). Tujuan dari AFE adalah untuk menentukan jumlah faktor atau dimensi bedasarkan atas hubungan korelasi antar butir (Buhner, 2011). Dalam konteks penelitian ini, AFE digunakan untuk menemukan jumlah dimensi yang terkandung dalam SEDKK. Metode ini juga dipilih sebagai metode pencarian faktor, karena dimensi-dimensi SEDKK terdiri dari bagian-bagian beberapa model psikologi kesehatan dan bukan bersumber dari satu teori atau model murni. Selain itu, AFE juga memberikan informasi tentang hubungan dimensi dengan butirbutirnya.

Pada tahapan pertama, uji Barlett-Test dan kriteria Kaiser-Meyer-Olkin (KMO) dilakukan untuk membuktikan apakah butirbutir dapat dianalisis secara stokastik. Dengan kata lain, kedua parameter tersebut juga bertujuan untuk mencari korelasi matrik antara indikator-indikator yang diobservasi (Widarjono, 2015). Dalam penilaiannya, hasil dari Barlett-Test harus memiliki nilai KaiKuadrat yang signifikan dan kriteria KMO harus di atas dari .50 (Buhner, 2011).

Ekstraksi butir dilakukan pada tahapan kedua. Ekstraksi faktor memiliki tujuan untuk mereduksi butir-butir yang sedang dianalisis sesuai dengan tingkat korelasinya (Backhaus et al., 2015). Hasil dari ekstraksi butir adalah jumlah faktor yang lebih kecil dari jumlah butir yang dianalisis (Bortz \& Schuster, 2010). Selain itu, faktor hasil ekstraksi biasanya tidak memiliki keterpautan dengan faktor yang lainnya (Buhner, 2011). Metode analisis komponen prinsipiel (principal component analysis) digunakan dalam penelitian ini untuk mengekstraksi butir-butir dari SEDKK. Penelitian ini juga menggunakan kriteria Kaiser-Gutmann dan Screeplot untuk memutuskan jumlah faktor atau dimensi ekstraksi butir. Dengan kata lain, eigenvalues dari faktor-faktor harus lebih besar daripada satu dan/atau titik-titik faktor pada Screeplot di atas dari nilai satu (Bortz \& Schuster, 2010; Buhner, 2011).

Tahap terakhir AFE adalah perotasian faktor. Penelitian ini menggunakan metode varimax untuk memaksimalkan factor loading dari setiap butir pada faktor yang paling terkorelasi dengannya secara ortogonal. Nilai factor loading yang ideal adalah sebuah butir 
memiliki factor loading $>.50$ terhadap sebuah faktor dan memiliki factor loading $<.30$ terhadap faktor-faktor yang lainnya (Buhner, 2011). Dari rotasi faktor, maka faktor atau dimensi yang muncul akan dapat diintepretasi sesuai dengan butir-butir yang terhimpun di dalamnya (Backhaus et al., 2015). Selain itu, Buhner (2011) menegaskan untuk berhati-hati dalam eliminasi butir yang meskipun memiliki factor loading rendah namun penting terhadap eksistensi dari dimensi yang terhubung dengannya. Tokoh tersebut juga mengungkapkan bahwa, jika sebuah butir penting untuk sebuah konstruk, maka meskipun butir itu memiliki factor loading yang rendah sebaiknya untuk tetap dimuat ke dalam faktor (Buhner, 2011).

\section{Pengujian konsistensi internal}

Koefisien Alpha Cronbach digunakan untuk memprediksi konsistensi internal dari SEDKK secara keseluruhan dan per dimensi. Koefisien Alpha Cronbach sendiri merupakan generalisasi dari nilai karakteristik, atau lebih dikenal dengan metode belah dua (split-half) dari Rulon (1993) yang dengannya, seseorang dapat memprediksi tingkat reliabilitas tanpa harus membagi kuesioner ke dalam dua bagian, tetapi menggunakan bagian tes dalam hal ini butir- sebagai bagian dari tes yang diuji (Meyer, 2004; Raju \& Guttman, 1965; Williams \& Zimmerman, 1966). Meskipun terdapat perbedaan pendapat tentang penafsiran dari koefisien Alpha
Cronbach di kalangan ilmuwan statistik, studi ini akan menerima dimensi-dimensi yang memiliki konsistensi internal $\geq .70$ (Schecker, 2014).

\section{Pengujian validitas konstruksi dan kriteria}

Dalam pengujian validitas SEDKK, terdapat dua aspek validasi yang dilakukan, yaitu uji validitas konstruksi dan kriteria. Validitas konstruksi melalui validitas konvergennya adalah keberlakuan atau keabsahan sebuah tes karena adanya korelasi yang signifikan antara dimensi yang diukurnya dan dimensi yang serupa dari tes yang berbeda (Buhner, 2011). Uji korelasi antara SEDKK dan Efikasi Diri Umum dilakukan untuk menguji validitas kontruksi dari SEDKK.

Validitas kriteria ditujukan untuk melihat keberlakuan dari sebuah tes berdasarkan fungsi dan kegunaannya dalam melakukan diagnosis terhadap perilaku manusia. Karena salah satu tujuan strategis dari SEDKK adalah -dalam konteks teori kognitif sosial- memprediksi perilaku sehat manusia, maka uji validitas kriteria dinilai krusial dalam penelitian ini (Buhner, 2011). Di saat SEDKK menjadi variabel prediktor, maka kesehatan umum, kepuasan, keseimbangan kehidupan kerja, perilaku hidup dan kerja sehat dan berisiko menjadi variabel kriteria dalam menganalisis regresi linier. Sistem pengkategorian efek dari SEDKK terhadap variabel-variabel kriteria mengacu kepada Cohen $(1988,1992)$. 


\section{Pengujian reliabilitas tes berulang (test- retest)}

Tujuan pengujian reliabilitas tes berulang dalam penelitian ini adalah untuk mengamati konsistensi dimensi-dimensi kuesioner di dua waktu yang berbeda (Meyer, 2004). Reliabilitas tes berulang dalam penelitian ini juga dijadikan parameter sekunder untuk menilai reliabilitas selain Alpha Cronbach karena Alpha Cronbach yang dinilai kurang cukup untuk menjadi indikator dalam menilai reliabilitas sebuah instrumen tes (McNeish, 2018; Sijtsma, 2009). Secara teori, sebuah alat ukur akan selalu mengukur hal yang seharusnya diukur tanpa adanya penyimpangan yang signifikan di waktu pengukuran yang berbeda. Dalam penilaiannya, parameter reliabilitas tes ulang adalah korelasi dan sebuah alat ukur akan memiliki reliabilitas tes ulang yang baik adalah jika memiliki korelasi mulai dari .80. Dalam penelitian ini, partisipan yang sama menjawab kuesioner yang sama di tiga waktu yang berbeda, yakni tanggal 25 Juni 2019, 02 Juli 2019, dan 30 Juli 2019. Namun, hanya data dari tanggal 25 Juni 2019 dan 30 Juli 2019 yang digunakan untuk penelitian ini untuk menganalisis SEDKK secara holistik pada tahap studi pendahuluan ini.

Agar dapat memaksimalkan peredaman variabel-variabel pengganggu, kedua pengambilan tes ini juga dilakukan di ruang kuliah serta pimpinan penelitian yang sama. Di antara kedua waktu pengambilan sampel, tidak ada pelatihan atau intervensi yang diberikan kepada partisipan. Kriteria eksklusi dilakukan untuk pengambilan sampel kedua. Data partisipan yang menjawab pertanyaan "Kapan Anda pertama kali menjadi partisipan dalam kuesioner penelitian ini?" dengan jawaban “Selasa, 02 Juli 2019” akan dieliminasi untuk tahap analisis statistik, karena data yang akan diolah untuk pengujian reliabilitas tes berulang adalah data dari tanggal 25 Juni 2019 dan 30 Juli 2019. Jika selanjutnya ada perbedaan antara jumlah peserta pada kedua waktu pengambilan sampel, maka uji distribusi normal akan dilakukan sebelum analisis korelasi untuk reliabilitas tes ulang dilaksanakan.

\section{Hasil}

Tabel 1 memberikan rangkuman dari hasil distribusi normal SEDKK dari kedua waktu pengambilan sampel. SEDKK dari kedua waktu pengambilan sampel secara umum memiliki distribusi normal. Akan tetapi, jika diamati di tingkat subskala, SEDKK tidak terdistribusi secara normal. Menyikapi hasil ini, maka pengujian reliabilitas tes berulang akan dilakukan pada tingkat skala umum. 


\section{Tabel 1}

Hasil Tes Shapiro-Wilk untuk Menguji Distribusi Normal SEDKK dan Subskalanya

\begin{tabular}{lcccc}
\hline & \multicolumn{2}{c}{$\mathrm{T} 1$} & \multicolumn{2}{c}{$\mathrm{T} 2$} \\
\hline & \multicolumn{2}{c}{$d f=44$} & \multicolumn{2}{c}{$d f=38$} \\
SEDKK & $\mathrm{W}$ & $p$ & $\mathrm{~W}$ & $P$ \\
\cline { 2 - 6 } Perilaku makan dan minum & .972 & .348 & .941 & .05 \\
Perilaku tidur & .933 & $<.05$ & .892 & $<.01$ \\
Perilaku keamanan dan keselamatan kerja & .966 & .213 & .895 & $<.01$ \\
Perilaku pemulihan stres kerja & .940 & $<.05$ & .875 & $<.001$ \\
\hline
\end{tabular}

Catatan. T1 = 25 Juni 2019; T2 = 30 Juli 2019.

Pada tahap pertama, AFE dilakukan untuk mengeksplorasi jumlah dimensi atas dasar korelasi yang muncul akibat dari jawaban partisipan. Tes Barlett menyatakan bahwa $\chi^{2}(91)=405.584(\mathrm{p}<.001)$ dan kriteria KMO memiliki nilai sebanyak .795 yang dapat ditafsirkan dengan peringkat "cukup"
(Backhaus et al., 2015). Dengan demikian, butir-butir SEDKK memenuhi syarat untuk dianalisis dengan AFE. Hasil AFE menyebutkan bahwa ada empat faktor -dimensi- yang masih memiliki initial eigenvalues lebih dari satu setelah proses ekstraksi dari butir-butir SEDKK, yaitu 1.171.

\section{Gambar 1}

Screeplot dari AFE untuk SEDKK

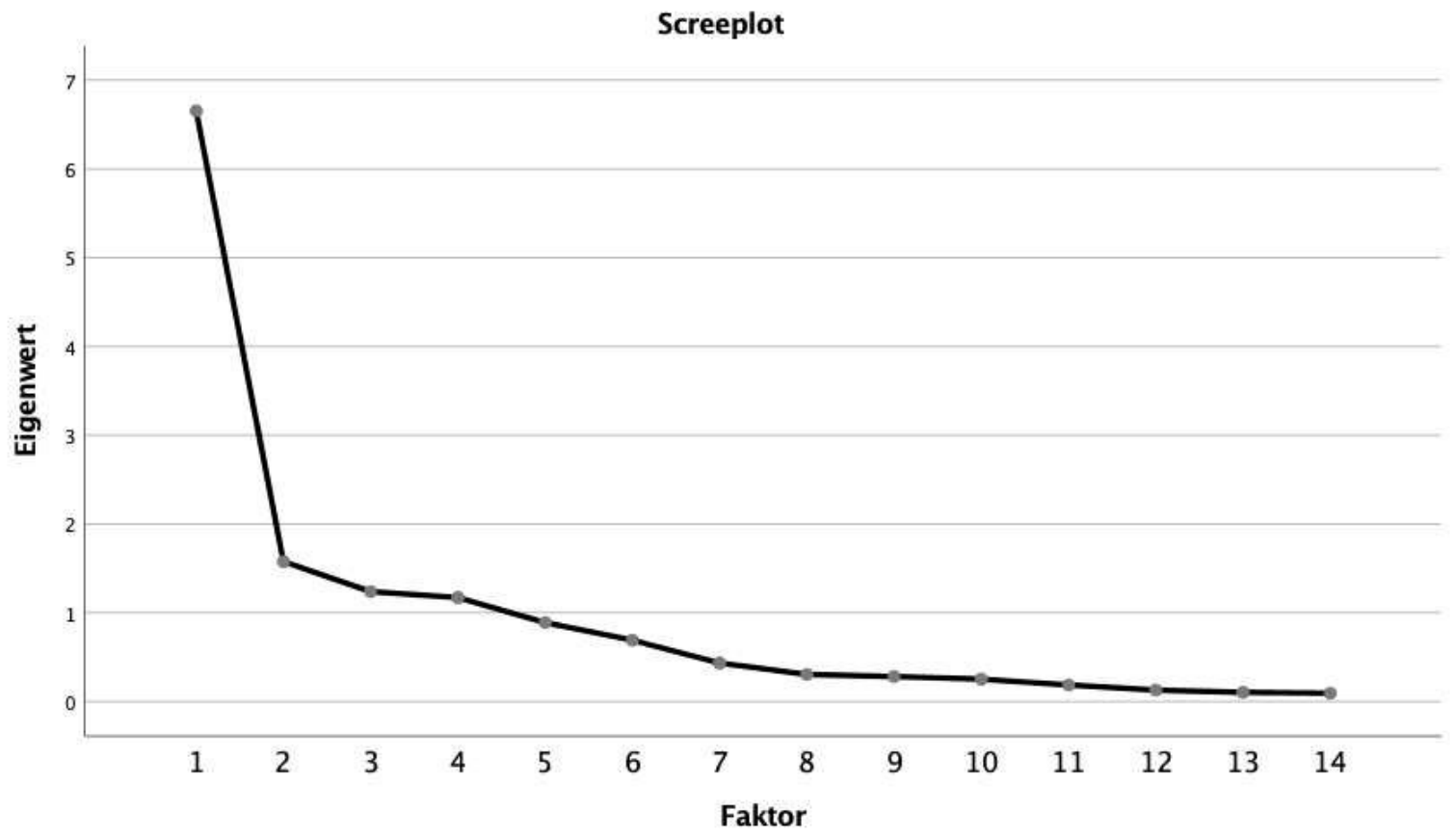


Di samping itu dengan melihat hasil dari Screeplot, ada empat titik -dimensi- yang memenuhi kriteria Kaiser-Guttman dengan melampaui initial eigenvalues lebih dari satu (Gambar 1). Dengan demikian, empat faktor determinasi untuk kesehatan kerja pada SEDKK dapat tereduksi dengan dikelompokkannya butir-butir SEDKK ke dalam empat faktor setelah dilakukannya AFE.

Tabel 2 menunjukan factor loading dari butir-butir SEDKK terhadap komponenkomponen matriks setelah dirotasi secara varimax. Pengintepretasian dari Tabel 2 akan disajikan di bagian pembahasan. Sedangkan konsistensi internal dari SEDKK dari waktu pengambilan sampel pertama di tingkat umum memiliki Alpha Cronbach .911. Pada tingkat dimensional konsistensi internal SEDKK berkisar antara .763 hingga .859. Dari waktu pengambilan sampel kedua, SEDKK memiliki Alpha Cronbach .916 dan pada tingkat dimensional antara .802 dan .923. Dengan melihat parameter yang diajukan oleh Schmidt (Schecker, 2014), SEDKK dari kedua waktu memiliki konsistensi internal dengan peringkat antara dapat diterima hingga sangat baik. 
Tabel 2

SEDKK (T1) dan Factor Loading Setelah Dirotasi dengan Metode Varimax

\begin{tabular}{|c|c|c|c|c|c|c|c|}
\hline \multirow[b]{2}{*}{ Kode } & \multicolumn{2}{|l|}{ Pernyataan-pernyataan pada SEDKK } & \multicolumn{3}{|c|}{ Komponen $^{*}$} & \multirow[b]{2}{*}{$M !$} & \multirow[b]{2}{*}{$S D !$} \\
\hline & $\begin{array}{l}\text { Sesibuk apapun atau sesulit apapun masalah } \\
\text { yang sedang saya hadapi selama tiga bulan } \\
\text { terakhir... }\end{array}$ & 1 & 2 & 3 & 4 & & \\
\hline wrk & ...saya bisa bekerja dengan selamat dengan & .786 & & & & 4.0 & .82 \\
\hline 1 & $\begin{array}{l}\text { memperhatikan faktor kesehatan dan } \\
\text { keselamatan kerja. }\end{array}$ & & & & & 7 & \\
\hline wrk & ...saya akan selalu menjalankan pola kerja & .757 & .446 & & & 3.6 & .96 \\
\hline 2 & tanpa mengabaikan kesehatan saya. & & & & & 8 & \\
\hline wrk & ...saya bisa pulang bekerja dengan kondisi & .687 & & & .323 & 3.9 & .79 \\
\hline 3 & yang sehat. & & & & & 8 & \\
\hline wrk & ...saya bisa menjalankan pola kerja tanpa & .600 & .580 & & & 4.0 & .93 \\
\hline 4 & mengabaikan keselamatan saya. & & & & & 2 & \\
\hline rcv1 & $\begin{array}{l}\text {...saya akan selalu menyempatkan diri untuk } \\
\text { melakukan aktivitas fisik yang menunjang } \\
\text { kesehatan saya. }\end{array}$ & .597 & & .469 & .419 & $\begin{array}{l}3.4 \\
8\end{array}$ & .66 \\
\hline rcv2 & $\begin{array}{l}\text {...saya akan selalu menyempatkan diri untuk } \\
\text { berolahraga secara teratur. }\end{array}$ & .577 & & 443 & .432 & $\begin{array}{l}3.3 \\
2\end{array}$ & 9.80 \\
\hline eat1 & $\begin{array}{l}\text {...saya bisa memenuhi kebutuhan cairan per } \\
\text { hari saya. }\end{array}$ & & .849 & & & $\begin{array}{l}3.7 \\
7\end{array}$ & 1.01 \\
\hline eat2 & $\begin{array}{l}\text {...saya tetap bisa menjalankan pola makan } \\
\text { dan minum yang beragam, bergizi seimbang } \\
\text { dan aman. }\end{array}$ & & .777 & & .307 & $\begin{array}{l}3.4 \\
5\end{array}$ & .85 \\
\hline eat3 & $\begin{array}{l}\text {...saya mampu menjalankan pola makan yang } \\
\text { sehat. }\end{array}$ & & .743 & .401 & .333 & $\begin{array}{l}3.5 \\
2\end{array}$ & .88 \\
\hline slp1 & $\begin{array}{l}\text {...saya bisa menjaga waktu tidur saya setiap } \\
\text { malam berkisar antara } 6-8 \text { jam. }\end{array}$ & & & .892 & & $\begin{array}{l}3.2 \\
7\end{array}$ & .87 \\
\hline $\operatorname{slp} 2$ & $\begin{array}{l}\text {...saya mampu menjalankan pola tidur sehat } \\
\text { yang sehat. }\end{array}$ & & .437 & .796 & & $\begin{array}{l}3.2 \\
5\end{array}$ & .78 \\
\hline slp3 & ...saya akan bisa untuk tidur nyenyak. & .373 & & .468 & & $\begin{array}{l}3.5 \\
0\end{array}$ & .76 \\
\hline rcv3 & $\begin{array}{l}\text {....saya bisa menyempatkan diri untuk } \\
\text { melakukan aktivitas sosial (contoh: bertemu } \\
\text { dengan teman-teman, bertamasya dengan } \\
\text { keluarga, dan sebagainya.). }\end{array}$ & & & & .891 & $\begin{array}{l}4.1 \\
1\end{array}$ & .78 \\
\hline $\operatorname{rcv} 4$ & $\begin{array}{l}\text {....saya bisa menyempatkan diri untuk } \\
\text { menjalankan hobi atau kegemaran saya } \\
\text { (contoh: membaca, bermain video game, dan } \\
\text { sebagainya.). }\end{array}$ & & & & .846 & $\begin{array}{l}3.9 \\
1\end{array}$ & .86 \\
\hline & Alpha Cronbach (T1) & .859 & .850 & .763 & .836 & & $11 \S$ \\
\hline & Alpha Cronbach (T2) & .923 & .874 & .802 & .814 & & $16 \S$ \\
\hline
\end{tabular}

Catatan. Nilai factor loading yang kurang dari .300 tidak diikutsertakan ke dalam AFE (Bühner, 2011). wrk = perilaku keamanan dan keselamatan kerja; $\mathrm{rcv}=$ perilaku pemulihan stres kerja; eat = perilaku makan dan minum; slp = perilaku tidur; T1 = 20 Juni 2019; T2 = 30 Juli 2019; $M$ = ratarata; $S D=$ Standar Deviasi; ! = T1; ${ }^{\S}=$ Alpha Cronbach keseluruhan.

Hasil dari analisis regresi yang disajikan di Tabel 3 menyebutkan bahwa, SEDKK memiliki efek positif yang signifikan terhadap kesehatan umum. Selebihnya, satu poin peningkatan SEDKK, memengaruhi kesehatan umum dengan peningkatan sebesar 1.328 poin. 
Sementara itu, 15\% dari variansi kesehatan umum dapat dijelaskan melalui SEDKK. Meskipun demikian, efek dari SEDKK terhadap kesehatan umum sebesar $\left(f^{2}=.179\right)$ dapat dinilai rendah menurut Cohen (1988; 1992).

Kepuasan terhadap kondisi kesehatan pribadi akan mengalami peningkatan sebesar .599 dengan satu poin peningkatan yang muncul pada SEDKK. Skala ini sendiri dapat menjelaskan pengaruhnya terhadap variabel kriteria kepuasan sebesar 15\% dari variansinya. Di sisi lain, SEDKK memiliki efek yang kecil terhadap kepuasan. SEDKK juga berpengaruh terhadap tingkat keseimbangan kehidupan kerja dengan 29\% variansi yang dikandungnya. Dengan meningkatnya SEDKK sebesar satu poin, maka keseimbangan kehidupan kerja dapat meningkat sebesar .636 poin. SEDKK juga memiliki pengaruh terhadap keseimbangan kehidupan kerja yang terbilang besar.

SEDKK dapat menjelaskan pengaruhnya terhadap Perilaku Kerja dan Hidup Sehat (PKHSehat) dengan $80 \%$ variansi yang dikandungnya. Ketika SEDKK meningkat satu poin, PKH-Sehat dapat meningkat sebesar 1.029 poin. SEDKK juga memiliki efek yang kuat terhadap PKHSehat. SEDKK juga memiliki pengaruh terhadap Perilaku Kerja dan Hidup Berisiko (PKH-Risiko) melalui 34\% variansi yang dimilikinya. Berbeda dengan keempat kriteria eksternal sebelumnya, SEDKK menunjukan regresi linier yang negatif terhadap perilaku kerja dan hidup berisiko. Jadi, dengan meningkatnya SEDKK sebesar satu poin, maka nilai PKH-Risiko turun sebesar -.366. Efek dari SEDKK terhadap PKH-Risiko juga dapat digolongkan sebagai efek yang besar.

\section{Tabel 3}

Hasil Uji Regresi Linier

\begin{tabular}{lcccccc}
\hline & $B$ & $S E B$ & $\beta$ & $R^{2}$ & $F(1,42)$ & $f^{2}$ \\
\cline { 2 - 7 } Kesehatan & 1,328 & .484 & $.390^{* *}$ & .152 & $7,521^{* *}$ & .179 \\
Umum & .599 & .219 & $.389^{* *}$ & .151 & $7,499^{* *}$ & .178 \\
Kepuasan & .636 & .123 & $.624^{* * *}$ & .389 & $26,793^{* * *}$ & .637 \\
KKK & 1,029 & .79 & $.895^{* * *}$ & .800 & $168,160^{* * *}$ & 4,000 \\
PKH-Sehat & -.366 & .078 & $-.586^{* * *}$ & .344 & $22,007^{* * *}$ & .524 \\
PKH-Risiko & &
\end{tabular}

Catatan. $B=$ koefisien regresi; $S E B=$ standard error dari koefisien regresi; $\beta=$ koefisien regresi terstandar; $R^{2}=$ koefisien determinasi; $f^{2}=$ koefisien efek; KKK = Keseimbangan Kehidupan Kerja; PHK-Sehat = Perilaku Hidup dan Kerja Sehat, PHK-Risiko = Perilaku Hidup dan Kerja Berisiko; ${ }^{* *} \mathrm{p}<.01{ }^{* * *} \mathrm{p}<.001$.

Validasi konstruk dari SEDKK dilakukan dengan penghitungan korelasi antara SEDKK dan Efikasi Diri Umum (Tabel 4) dari waktu pengambilan sampel pertama. SEDKK memiliki korelasi positif yang sangat signifikan dengan Efikasi Diri Umum $(r=.47, p<.01)$. Dengan demikian, konstruk SEDKK dapat dinilai tervalidasi oleh Efikasi Diri Umum. Namun, seperti yang disajikan pada Tabel 4, SEDKK dari waktu pertama dan kedua tidak dapat menunjukan reliabilitas tes berulang Efikasi Diri Umum $(r=-.21, p=.208)$. 


\section{Tabel 4}

Korelasi antara SEDKK dan Variabel-Variabel Penguji Validitas Diskriminasi pada T1 dan T2

\begin{tabular}{|c|c|c|c|c|c|c|c|c|c|c|c|}
\hline $\mathrm{T} 2$ & 1 & 2 & 3 & 4 & 5 & 6 & 7 & $8 !$ & 9 & 10 & 11 \\
\hline 1 SEDKK & $(-0,21)$ & $0,81^{* *}$ & $0,74 * *$ & $0,82^{* *}$ & $0,83^{* *}$ & $0,51^{* *}$ & $0,52^{* *}$ & - & $0,70^{* *}$ & $0,92^{* *}$ & $-0,62^{* *}$ \\
\hline 2 -makan & $0,80^{* *}$ & $\left(-0,35^{*}\right)$ & $0,56^{* *}$ & $0,56^{* *}$ & $0,52^{* *}$ & $0,41^{*}$ & $0,42^{* *}$ & - & $0,50^{* *}$ & $0,76^{* *}$ & $-0,57^{* *}$ \\
\hline 3 -tidur & $0,75^{* *}$ & $0,50^{* *}$ & $(-0,01)$ & $0,40^{*}$ & $0,49^{* *}$ & $0,49^{* *}$ & $0,42^{* *}$ & - & $0,43^{* *}$ & $0,70^{* *}$ & $-0,58^{* *}$ \\
\hline 4 -kerja & $0,87^{* *}$ & $0,62^{* *}$ & $0,52^{* *}$ & $(-0,08)$ & $0,61^{* *}$ & $0,35^{*}$ & $0,40^{*}$ & - & $0,73^{* *}$ & $0,76^{* *}$ & $-0,44^{* *}$ \\
\hline 5 -pemulihan & $0,81^{* *}$ & $0,49^{* *}$ & $0,51^{* *}$ & $0,59^{* *}$ & $(0,13)$ & $0,42^{* *}$ & $0,42^{* *}$ & - & $0,52^{* *}$ & $0,69 * *$ & $-0,40^{*}$ \\
\hline 6 Kesehatan Umum & $0,39 * *$ & 0,22 & $0,42^{* *}$ & 0,21 & $0,45^{* *}$ & $(-0,08)$ & $0,77^{* *}$ & - & $0,45^{* *}$ & $0,44^{* *}$ & $-0,28$ \\
\hline 7 Kepuasan & $0,40^{* *}$ & 0,23 & $0,44^{* *}$ & 0,26 & $0,37^{*}$ & $0,70^{* *}$ & $(-0,14)$ & - & $0,39 *$ & $0,48^{* *}$ & $-0,18$ \\
\hline $8 \mathrm{GSE} !$ & $0,43^{* *}$ & $0,38^{*}$ & 0,17 & $0,30^{*}$ & $0,51^{\text {** }}$ & 0,16 & 0,23 & $1 !$ & - & - & - \\
\hline $9 \mathrm{WLB}$ & $0,62^{* *}$ & $0,34^{*}$ & $0,62^{* *}$ & $0,50^{* *}$ & $0,59 * *$ & $0,44^{* *}$ & $0,40^{* *}$ & 0,25 & $(0,02)$ &, $71^{* *}$ &,$- 42^{* *}$ \\
\hline 10 PHK-Seh & $0,58^{* *}$ & $0,36^{*}$ & $0,33^{*}$ & $0,56^{* *}$ & $0,55^{* *}$ & 0,03 & 0,12 & 0,08 & $0,36^{*}$ & $(-0,15)$ &,$- 53^{* *}$ \\
\hline 11 PHK-Risiko & $-0,59^{* *}$ & $-0,52^{* *}$ & $-0,66^{\text {** }}$ & $-0,45^{* *}$ & $-0,33^{*}$ &,$- 32 *$ & $-0,16$ & $-0,10$ &,$- 45^{* *}$ & $-0,30$ & $\left(-, 34^{*}\right)$ \\
\hline
\end{tabular}

Catatan. T1 = 20 Juni 2019; T2 = 30 Juli 2019; makan = perilaku makan dan minum; tidur = perilaku tidur; kerja = perilaku keamanan dan keselamatan kerja; pemulihan = perilaku pemulihan stres kerja; KKK = Keseimbangan Kehidupan Kerja; PHK-Sehat = Perilaku Hidup dan Kerja Sehat; PHKRisiko = Perilaku Hidup dan Kerja Berisiko; nilai pada diagonal (dalam kurung) $=$ korelasi antara T1 dan T2; nilai di bawah diagonal = korelasi pada T1; nilai di atas diagonal = korelasi pada T2; $p<$ .05 ; $^{* *} p<.01 ;$ ! $^{\prime}$ Analisis korelasi hanya pada T1.

\section{Pembahasan}

Tujuan dari penelitian ini adalah untuk menguji secara eksploratif apakah empat faktor determinasi dalam SEDKK juga muncul setelah dilakukan Analisis Faktor Eksploratori (AFE). Selain itu penelitian ini juga ingin menguji apakah SEDKK memiliki validitas konstruk melalui hubungan yang adekuat dengan konstruk efikasi diri yang diukur dengan instrumen yang berbeda. Dalam hal ini, Efikasi Diri Umum yang diukur adalah dengan General Self-Efficacy (GSE) oleh Schwarzer dan Jerusalem (1995). Selanjutnya validitas kriteria diuji melalui kemampuan SEDKK dalam memprediksi perilaku sehat, kondisi kesehatan, kepuasan atas kesehatan pribadi, keseimbangan kehidupan kerja, dan perilaku berisiko. Selain melihat Alpha Cronbach sebagai koefisien untuk konsistensi internal sebuah konstruk dan indikator dari reliabilitas sebuah instrumen tes, penelitian ini juga menguji reliabilitas tes berulang SEDKK dari dua waktu yang berbeda.

Munculnya empat faktor atau dimensi yang diperoleh dari AFE memberikan tanda bahwa butir-butir yang diformulasikan memiliki kemungkinan besar dalam mencerminkan empat dimensi dalam efikasi diri untuk kesehatan kerja seperti yang telah dijelaskan di atas. Akan tetapi, jika melihat lebih dalam kepada tingkatan factor loading, ada kerancuan-kerancuan yang muncul. Hasil dari rotasi faktor dengan metode varimax adalah pengelompokan butir-butir sesuai dengan kemiripannya yang telah dianalisis melalui derajat korelasinya. Pada penelitian ini, hampir seluruh butir bermanifestasi ke dalam faktor atau dimensi yang telah dikonsepkan secara 
teori sebelumnya, kecuali butir slp2, rcv1, dan rcv2 seperti dimuat pada Tabel 2. Faktor pertama dengan keempat butir keamanan dan kesehatan kerja tanpa kedua butir pertama dari dimensi pemulihan setelah bekerja dapat ditafsirkan sebagai dimensi keamanan dan kesehatan kerja. Jika faktor pertama dianalisis dengan tambahan dua butir pemulihan dan satu butir dari perilaku tidur, maka dikhawatirkan akan terjadi kerancuan pada konstruksi itu sendiri. Di sisi lain, butir rcv1 dan rcv2 tersebut juga memiliki factor loading yang masih dapat diterima eksistensinya di faktor keempat. Namun, hal ini sudah terantisipasi dengan kaidah pengeliminasian dan penafsiran hasil AFE yang direkomendasikan oleh Bühner (2011). Dengan demikian, untuk tahapan pengujian konsistensi internal butir rcv1 dan rcv2, akan diolah bersamaan dengan faktor keempat dan bukan faktor pertama.

Butir-butir perilaku makan sehat saling bertautan satu dengan yang lainnya sehingga faktor kedua dapat ditafsirkan secara jelas. Pada faktor ketiga, ada dua butir perilaku tidur sehat yang memiliki factor loading yang tinggi di dalamnya. Hal yang menjadi permasalahan adalah butir slp2 dengan factor loading relatif seimbang secara bersamaan ke dalam faktor pertama dan faktor ketiga. Namun, karena factor loading slp3 lebih tinggi untuk faktor ketiga dibandingkan dengan faktor pertama dan sisi makna lebih memiliki kecenderungan terhadap faktor ketiga, maka untuk tahap pengujian konsistensi internal, slp2 akan diikutsertakan ke dalam faktor ketiga atau dimensi perilaku tidur sehat. Faktor keempat dengan butir rcv3 dan rcv4 yang tinggi dan rcv1 dan rcv2 yang masih dapat dipertimbangkan eksistensinya dengan kerancuannya pada factor loading-nya akan disikapi sebagai satu faktor.

Namun hasil AFE untuk SEDKK pada penelitian ini juga menemukan hal yang menarik tentang persepsi partisipan atas aktivitas pemulihan setelah bekerja yang pada SEDKK dikategorikan sebagai dimensi perilaku pemulihan dari stres kerja. Pada penelitian ini, partisipan memberikan impresi, bahwa aktivitas fisik penunjang kesehatan atau olahraga masih dapat dikategorikan sebagai aktivitas yang dapat membebani partisipan sehingga muncul ke dalam dimensi keamanan dan keselamatan kerja. Hal ini mungkin juga dapat diinterpretasikan bahwa, olahraga masih dinilai sebagai keharusan dan bukan kebutuhan bagi partisipan. Fenomena ini bisa menjadi agenda tersendiri bagi penelitipeneliti yang bergerak di bidang psikologi lintas budaya. Dengan demikian, jumlah butir yang menyangkut dengan olahraga bisa dikembangkan lebih banyak dari SEDKK yang sedang dikembangkan pada penelitian ini. Selain penambahan jumlah butir dan perluasan jumlah partisipan, analisis faktor eksploratori juga sangat disarankan pada tahap pengembangan selanjutnya untuk memastikan apakah keempat faktor SEDKK tidak hanya muncul karena hubungan korelasi semata, 
namun juga merefleksikan konstruksi sesuai dengan konsep yang diilustrasikan dari keempat faktor atau dimensi tersebut (Bühner, 2011).

Hubungan yang adekuat antara konstruk efikasi diri yang diukur oleh instrumen SEDKK maupun Efikasi Diri Umum memberikan sinyal positif untuk pengembangan lanjutan dari SEDKK di masa yang akan datang. Namun demikian, pernyataan ini tidak memberikan kepastian jika SEDKK kedepan mengalami revisi dan peningkatan jumlah partisipan. Selain itu hubungan antara SEDKK dan Efikasi Diri Umum dapat dinilai dengan korelasi sedang. Walaupun begitu, hasil ini dinilai memuaskan karena partisipan melihat kesamaan maknawi yang terkandung pada kedua tes tersebut dan kewajaran dari sedangnya tingkat korelasi yang mungkin dapat dijelaskan oleh kekhususan dari SEDKK yang mengukur efikasi diri dalam konteks kesehatan kerja.

Seperti yang disajikan di Tabel 4, SEDKK memiliki hubungan korelatif terhadap variabel kriteria pada penelitian ini, seperti kesehatan umum, kepuasan dengan kondisi kesehatan pribadi, keseimbangan kehidupan kerja, perilaku sehat, dan perilaku berisiko. Namun demikian, hal ini tidak cukup untuk mengatakan apakah validitas kriteria SEDKK akan kemampuannya untuk memprediksi variabel-variabel tersebut eksis. Dengan demikian, analisis regresi linier sederhana seperti yang disajikan di Tabel 3 kiranya penting sebagai pendalaman hubungan korelatif antara SEDKK dengan setiap kriteriakriteria eksternalnya.

Hasil dari analisis regresi linier sederhana menilai bahwa SEDKK adalah sebuah tes yang valid untuk memprediksi variabel-variabel yang bersangkutan dengannya, karena eksistensi variabilitas SEDKK pada setiap variabel luaran (outcome variable) muncul secara tidak tiba-tiba, namun juga memiliki efek yang dapat dipertanggungjawabkan kemunculannya. Namun yang menjadi perhatian adalah tingginya koefisien determinasi dan efek yang muncul dari SEDKK terhadap Perilaku Kerja dan Hidup Sehat (PKH-Sehat). Kemungkinan besar hal ini terjadi karena pendeknya waktu pengambilan data pada penelitian ini, sehingga muncul bias atau distorsi emosi ketika menjawab PKH-Sehat sesaat setelah SEDKK. Dengan demikian penelitian ini merekomendasikan untuk penelitian agar melihat perilaku sehat tidak langsung setelah SEDKK dilakukan.

Selanjutnya, melalui Tabel 4 dapat diketahui bahwa hasil analisis korelasi antara kedua nilai SEDKK dari waktu yang berbeda adalah korelasi negatif yang tidak signifikan. Artinya, SEDKK belum dapat memperlihatkan reliabilitas tes berulang. Ada banyak faktor yang menentukan mengapa reliabilitas tes berulang tidak terjadi, seperti: (a) kondisi mental partisipan (motivasi), (b) lingkungan (suhu ruangan tes), (c) penampilan 
administrator tes, atau (d) sinyal jaringan telekomunikasi yang berbeda antara kedua waktu. Penelitian mendatang diharapkan dapat memperhatikan dan mengontrol faktor-faktor yang dapat memengaruhi reliabilitas khususnya reliabilitas tes berulang.

Meskipun SEDKK dapat dikatakan masih pada tahap pengembangan, tes ini sudah dapat diimplementasikan pada ranah yang dicakupnya. Contohnya dalam menunjang keamanan di tempat kerja, SEDKK dapat digunakan untuk menurunkan langkahlangkah penyuluhan yang sesuai dengan profil departemen sesuai dengan nilai rata-rata SEDKK-nya. Misalnya departemen tersebut memiliki nilai rata-rata perilaku tidur dari SEDKK yang lebih rendah dari rata-rata perilaku tidur SEDKK perusahaan. Maka ketika manajemen ingin melakukan penyuluhan atau workshop kepada departemen itu, sebaiknya manajemen menitikberatkan tentang pentingnya menjaga pola tidur sehat. Dalam implikasinya, SEDKK masih merupakan produk dari studi pengantar yang harus digunakan secara hati-hati karena ketidakmampuannya dalam menunjukkan reliabilitas tes berulang.

SEDKK juga merupakan tes yang dirancang untuk memenuhi kebutuhan para praktisi Psikologi Industri dan Organisasi dalam mendiagnosis peristiwa-peristiwa yang terjadi di tempat kerja dan membutuhkan penjelasan yang mungkin disebabkan oleh perilakuperilaku yang berisiko di tempat kerja.
Penjelasan tersebut tentunya dapat diawali dengan melihat tingkat efikasi diri karyawan. Mengingat proses diagnostik organisasi yang selalu berlomba dengan waktu, maka kepadatan dan ketepatan menjadi faktor penting dalam pengembangan instrumen tersebut. Skala Efikasi Diri untuk Kehidupan Kerja dalam pengembangannya juga telah memperhatikan faktor-faktor tersebut, sehingga praktisi di bidang kesehatan terapan dan Psikologi Industri dan Organisasi mampu bertindak cepat dan tepat dalam menangani permasalahan yang muncul di tempat kerja. Hal ini dibuktikan dengan tingkat konsistensi internal SEDKK yang dapat dipertanggungjawabkan, baik secara umum maupun dimensional. Di samping itu pula, SEDKK dalam penelitian ini juga memperlihatkan hubungannya yang signifikan dengan Efikasi Diri Umum dan kekuatannya untuk memprediksi konstruk-konstruk kondisi kejiwaan yang berkorelasi dengan perilaku sehat.

Representasi SEDKK masih dapat dikatakan terbatas, karena sampel yang digunakan pada penelitian ini adalah mahasiswa dan bukan orang yang bekerja berdasarkan ikatan hubungan kerja. Dengan demikian, sampel yang sesuai dengan populasi yang dituju -karyawan- patut diperhatikan dalam penelitian-penelitian yang akan datang. Sampel yang terbatas pada studi pengantar ini juga patut dikritisi dan untuk penelitian selanjutnya penambahan jumlah sampel sangat 
dianjurkan (Buhner, 2011). Jumlah sampel yang memadai juga menjadi syarat utama jika Analisis Faktor Konfirmatori (AFK) atau metode persamaan struktural (structural equation model) ingin dilakukan (Weiber \& Mühlhaus, 2014). Selain itu, penambahan butir juga penting untuk dilakukan, terlepas apakah nantinya sejumlah butir akan dilepas dari faktornya, yang mungkin bisa disebabkan karena rendahnya factor loading. Bagi penelitian selanjutnya, keterlibatan praktisipraktisi yang berkecimpung di bidang keselamatan dan kesehatan kerja atau Psikologi Industri dan Organisasi dinilai penting untuk memberikan evaluasi serta masukan terhadap konstruksi skala demi peningkatan kualitas dan validitas eksternal rupa (face validity). Di samping itu, konsep efikasi diri yang berorientasi kepada teori kognitif sosial juga patut diolah secara psikologi lintas budaya dan dicari sisi yang dapat terintegrasi dengan kultur dari populasi yang dituju pada penelitian selanjutnya.

\section{Simpulan}

Skala Efikasi Diri untuk Kesehatan Kerja (SEDKK) adalah instrumen untuk mengukur penilaian subjektif efikasi diri yang berhubungan dengan perilaku sehat bagi individu-individu yang terikat hubungan kerja. Pada penelitian ini, SEDKK terindikasi memiliki empat dimensi yang mencerminkan perilaku konsumsi sehat, pola tidur sehat, keamanan dan kesehatan kerja, serta kegiatan bebas di luar kerja. Skala ini juga dinilai sebagai sebuah instrumen yang reliabel berdasarkan konsistensi internalnya dan valid berdasarkan korelasinya dengan Efikasi Diri Umum dan kemampuannya untuk memprediksi perilaku sehat, kondisi kesehatan, kepuasan atas kesehatan pribadi, dan keseimbangan kehidupan kerja.

\section{Saran}

Pada tahap pengembangan selanjutnya, penelitian selanjutnya perlu melakukan penambahan jumlah butir, penambahan jumlah partisipan, dan penggunaan analisis faktor konfirmatori untuk mendapatkan hasil penelitian yang lebih stabil. Dalam pengimplementasiannya, nilai rata-rata SEDKK seseorang dapat direlasikan terhadap nilai rata-rata SEDKK sebuah kelompok sehingga dapat digunakan untuk memotret sebaran skor dan kecenderungan skor individu secara lebih baik.

\section{Referensi}

Backhaus, K., Erichson, B., Plinke, W., \& Weber, R. (2015). Multivariate analysemethoden: Eine anwendungsorientierte Einfuhrung. In Multivariate analysemethoden. Springer Gabler.

Bakker, A. B., \& Demerouti, E. (2007). The job demands-resources model: State of the art. Journal of Managerial Psychology, 22(3), 309-328. https:// d o i . o r g / 10 . 11108 / 02683940710733115

Bandura, A. (1994). Self-efficacy. In V. S. Ramachaudran (Ed.), Encyclopedia of human behavior (Vol. 4, pp. 71-81). Academic Press. 
Bandura, A. (1982). Self-efficacy mechanism in human agency. American Psychologist, 37(2), 122-147. https://doi.org/ 10.1037/0003-066X.37.2.122

Bandura, A. (1997). Self-efficacy: The exercise of control. W H Freeman/Times Books/ Henry Holt \& Co.

Bandura, A. (2004). Health promotion by social cognitive means. Health Education and Behavior, 31(2), 143-164. h t tps://doi.org/10.117 / / 1090198104263660

Banik, A., Schwarzer, R., Knoll, N., Czekierda, K., \& Luszczynska, A. (2018). Self-efficacy and quality of life among people with cardiovascular diseases: A meta-analysis. 63(2), 295-312. https://doi.org/ $10.1037 /$ rep0000199

Barnes, C. M. \& Drake, C. L. (2015). Prioritizing sleep health: Public health policy recommendations. Perspectives on Psychological Science, 10(6), 733-737. h t tp s://doi.org/10.1177/ 1745691615598509

Barnes, C. M., Schaubroeck, J., Huth, M., \& Ghumman, S. (2011). Lack of sleep and unethical conduct. Organizational Behavior and Human Decision Processes, 115(2), 169-180. https://doi.org/ 10.1016/j.obhdp.2011.01.009

Betz, N. E., Klein, K. L., \& Taylor, K. M. (1996). Evaluation of a short form of the career decision-making self-efficacy scale. Journal of Career Assessment, 4(1), 4757. https://doi.org/10.1177/ 106907279600400103

Beus, J. M., Dhanani, L. Y., \& McCord, M. A. (2015). A meta-analysis of personality and workplace safety: Addressing unanswered questions. Journal of Applied Psychology, 100(2), 481-498. https://doi.org/10.1037/a0037916

Born, A., Schwarzer, R., \& Jerusalem, M. (1995). Indonesian adaptation of the General SelfEfficacy Scale. Freien Universität Berlin. http: / / u serpage.fu-berlin.de / \%7B \%7Dhealth/indonese.htm
Bortz, J., \& Schuster, C. (2010). Statistik fur human- und sozialwissenschaftler. Springer.

Branden, N. (2017). Die 6 säulen des selbstwertgefühls: erfolgreich und zufrieden durch ein starkes Selbst. Piper ebooks.

Brouwer-Goossensen, D., van Genugten, L., Lingsma, H. F., Dippel, D. W. J., Koudstaal, P. J., \& den Hertog, H. M. (2018). Selfefficacy for health-related behaviour change in patients with TIA or minor ischemic stroke. Psychology \& Health, 33(12), 1490-1501. https://doi.org/ 10.1080/08870446.2018.1508686

Brusso, R. C., Orvis, K. A., Bauer, K. N., \& Tekleab, A. G. (2012). Interaction among selfefficacy, goal orientation, and unrealistic goal-setting on videogame-based training performance. Military Psychology, 24(1), 1-18. https://doi.org/ 10.1080/08995605.2012.639669

Buhner, M. (2011). Einfuhrung in die Test- und Fregebogenkonstruktion, 3. Aufl. In Munchen: Pearson. Pearson.

Chang, V. T., Overall, N. C., Madden, H., \& Low, R. S. T. (2018). Expressive Suppression Tendencies, Projection Bias in Memory of Negative Emotions, and Well-Being. Emotion, 18(7), 925-941. https:// doi.org/10.1037/emo0000405

Chapman, G. B. (2019). A decision-science approach to health-behavior change. Current Directions in Psychological Science, 28(5), 469-474. https://doi.org/ 10.1177/0963721419854102

Cherian, J., \& Jacob, J. (2013). Impact of self efficacy on motivation and performance of employees. International Journal of Business and Management, 8(14), 80-88. https://doi.org/10.5539/ijbm.v8n14p80

Cohen, J. (1988). Statistical power analysis for the behavioral sciences (2nd ed.). Lawrence Earlbaum Associates.

Cohen, J. (1992). A power primer. In Psychological Bulletin (Vol. 112, Issue 1, 
pp. 155-159). American Psychological Association. https://doi.org/10.1037/ 0033-2909.112.1.155

Conradie, C. S., Van Der Merwe Smit, E., \& Malan, D. P. (2016). Corporate health and wellness and the financial bottom line evidence from South Africa. Journal of Occupational and Environmental Medicine, 58(2), e45-e53. https://

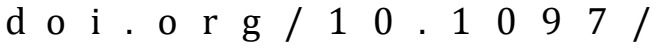
JOM.0000000000000653

Coogle, C. L., Hackett, L., Owens, M. G., Ansello, E. F., \& Mathews, J. H. (2016). Perceived self-efficacy gains following an interprofessional faculty development programme in geriatrics education. Journal of Interprofessional Care, 30(4), 483-492. https://doi.org/10.1080/ 13561820.2016.1177003

Craig, A. (1992). Symptoms of acute and chronic fatigue. In A. P. Smith \& D. M. Jones (Eds.), Handbook of human performance, , Vol. 1. The physical environment; Vol. 2. Health and performance; Vol. 3. State and trait (Vol. 3, pp. 289-339). Academic Press.

Csikszentmihalyi, M. (2008). Flow: The psychology of optimal experience. HarperCollins Publisher.

Dimotakis, N., Mitchell, D., \& Maurer, T. (2017). Positive and negative assessment center feedback in relation to development selfefficacy, feedback seeking, and promotion. Journal of Applied Psychology, 102(11), 1514-1527. https://doi.org/ $10.1037 / \mathrm{apl} 0000228$

Drake, C. L., Roehrs, T. A., Burduvali, E., Bonahoom, A., Rosekind, M., \& Roth, T. (2001). Effects of rapid versus slow accumulation of eight hours of sleep loss. Psychophysiology, 38(6), 979-987. https://doi.org/10.1111/14698986.3860979

Feng, X., Rost, D. H., \& Zhang, D. (2015). Akademische selbstwirksamkeit oder fachbezogene Selbstwirksamkeiten? [Academic self-efficacy or subject- specific self-efficacies?]. Zeitschrift Für Entwicklungspsychologie Und Pädagogische Psychologie, 47(3), 159172. https://doi.org/10.1026/00498637/a000132

Goodhines, P. A., Gellis, L. A., Ansell, E. B., \& Park, A. (2019). Cannabis and alcohol use for sleep aid: A daily diary investigation. Health Psychology, 38(11), 1036-1047. https://doi.org/10.1037/hea0000765

Grawe, van K., Donati, R., \& Bernauer, F. (2001). Psychotherapie im wandel: Von der konfession zur profession. Hogrefe.

Greenfield, B. L., Venner, K. L., Kelly, J. F., Slaymaker, V., \& Bryan, A. D. (2012). The impact of depression on abstinence self-efficacy and substance use outcomes among emerging adults in residential treatment Psychology of Addictive Behaviors/: Journal of the Society of Psychologists in Addictive Behaviors, 26(2), 246-254. https:// doi.org/10.1037/a0026917

Hou, C., Wu, Y., \& Liu, Z. (2019). Career decisionmaking self-efficacy mediates the effect of social support on career adaptability: A longitudinal study. Social Behavior and Personality, 47(5), e815. https://doi.org/ $10.2224 /$ sbp.8157

Huettermann, H., \& Bruch, H. (2019). Mutual gains? Health related HRM, collective well being and organizational performance. Journal of Management Studies, 56(6), 1045-1072. https:// doi.org/10.1111/joms.12446

ILO-SCORE. (2013). Keselamatan dan kesehatan kerja di tempat kerja: sarana untuk produktivitas Pedoman pelatihan untuk manajer dan pekerja Modul Lima. ILO.

Jankowska, A. M., £ockiewicz, M., DykalskaBieck, D., Eada, A., Owoc, W., \& Stañczykowski, D. (2017). Health behaviours in emerging adulthood: Their relationship with perceived maternal and paternal parental attitudes and the mediating role of self-efficacy. Health Psychology Report, 6(1), 94-108. https:/ /doi.org/10.5114/hpr.2018.71202 
Killgore, W. D. S., Balkin, T. J., \& Wesensten, N. J. (2006). Impaired decision making following $49 \mathrm{~h}$ of sleep deprivation. Journal of Sleep Research, 15(1), 7-13. https://doi.org/10.1111/j.13652869.2006.00487.x

Klassen, R. M., \& Chiu, M. M. (2010). Effects on teachers' self-efficacy and job satisfaction: Teacher gender, years of experience, and job stress. Journal of Educational Psychology, 102(3), 741-756. https://doi.org/10.1037/a0019237

Korinek, E. V, Phatak, S. S., Martin, C. A., Freigoun, M. T., Rivera, D. E., Adams, M. A., Klasnja, P., Buman, M. P., \& Hekler, E. B. (2018). Adaptive step goals and rewards: a longitudinal growth model of daily steps for a smartphone-based walking intervention. Journal of Behavioral Medicine, 41(1), 74-86. https://doi.org/10.1007/s10865-0179878-3

Kristensen, T. S., \& Borg, V. (2000). AMI's spørgeskema om psykisk arbejdsmiljø. In National Institute of Occupational Health. National Institute of Occupational Health.

Lachman, M. E., \& Weaver, S. L. (1998). The sense of control as a moderator of social class differences in health and well-being. Journal of Personality and Social Psychology, 74(3), 763-773. https://doi.org/10.1037//0022 3514.74.3.763

Lippke, S., \& Renneberg, B. (2006). Theorien und modelle des gesundheitsverhaltens. In B. Renneberg \& P. Hammelstein (Eds.), Gesundheitspsychologie (pp. 35-60). Springer Berlin Heidelberg. https:// doi.org/10.1007/978-3-540-47632-0_5

Maciejewski, P. K., Prigerson, H. G., \& Mazure, C. M. (2000). Self-efficacy as a mediator between stressful life events and depressive symptoms. Differences based on history of prior depression. The British Journal of Psychiatry/: The Journal of Mental Science, 176, 373-378. https:/ /doi.org/10.1192/bjp.176.4.373
Malanchini, M., Engelhardt, L. E., Grotzinger, A. D., Harden, K. P., \& Tucker-Drob, E. M. (2018). "Same but different": Associations between multiple aspects of self-regulation, cognition, and academic abilities. Journal of Personality and Social Psychology, 117(6), 1164-1188. https:// doi.org/10.1037/pspp0000224

McNeish, D. (2018). Thanks coefficient alpha, We'll take it from here. Psychological Methods, 23(3), 412-433. https:// doi.org/10.1037/met0000144

Meissel, K., \& Rubie-Davies, C. M. (2016). Cultural invariance of goal orientation and self-efficacy in New Zealand: Relations with achievement. British Journal of Educational Psychology, 86(1), 92-111. https://doi.org/10.1111/bjep.12103

Meyer, H. (2004). Theorie und qualitatsbeurteilung psychometrischer tests. Kohlhammer.

Park, Y. A., \& Sprung, J. M. (2015). Weekly work-school conflict, sleep quality, and fatigue: Recovery self efficacy as a cross level moderator. Journal of Organizational Behaviour, 36(1), 112-127. https:// doi.org/10.1002/job.1953

Park, Y., \& Kim, S. (2018). Customer mistreatment harms nightly sleep and next-morning recovery: Job control and recovery self-efficacy as cross-level moderators. Journal of Occupational Health Psychology, 24(2), 256-269. https://doi.org/10.1037/ocp0000128

Parkinson, J., Russell-Bennett, R., \& Previte, J. (2017). Challenging the planned behavior approach in social marketing: emotion and experience matter. European Journal of Marketing, 52(3/4), 837-865. https://doi.org/10.1108/EJM05-2016-0309

Pejabat Pelaksana Teknis Kegiatan Peningkatan Penganekaragaman Konsumsi Pangan. (2012). Petunjuk operasional kegiatan peningkatan percepatan penganekaragaman konsumsi pangan tahun anggaran 2012. Badan Ketahanan 
Pangan dan Penyuluhan Kabupaten Pesi. $\mathrm{h} \quad \mathrm{t} \quad \mathrm{t} \quad \mathrm{p} \quad \mathrm{s} / \mathrm{l}$ dinaspangan.pesisirselatankab.go.id/ t r a n s p a r a s i / f i l e / PO_Gerakan_Konsumsi_B2SA_2018.PDF

Pemerintah Indonesia. (1970). Undang-Undang Republik Indonesia Nomor 1 Tahun 1970 Tentang Keselamatan Kerja. Sekretariat Negara Republik Indonesia.

Pemerintah Indonesia. (1992). Undang-Undang Republik Indonesia Nomor 23 Tahun 1992 Tentang Kesehatan. Sekretariat Negara Republik Indonesia.

Pemerintah Indonesia. (2009). Peraturan Presiden (Perpres) No. 22 Tahun 2009 tentang Kebijakan Percepatan Penganekaragaman Konsumsi Pangan Berbasis Sumberdaya Lokal. Sekretariat Negara Republik Indonesia.

Perkonigg, A., Goodwin, R. D., Fiedler, A., Behrendt, S., Beesdo, K., Lieb, R., \& Wittchen, H. U. (2008). The natural course of cannabis use, abuse and dependence during the first decades of life. Addiction, 103(3), 439-449. https:/ / do i o r g / 10.1111 / j.1360 0443.2007.02064.x

Purnomo, R., \& Lestari, S. (2010). Pengaruh kepribadian, self-efficacy, dan locus of control terhadap persepsi kinerja usaha skala kecil dan menengah.Jurnal Bisnis Dan Ekonomi (JBE), 17(2), 144-160. https:// www.unisbank.ac.id/ojs/index.php/fe3/ article/download/333/217

Raju, N. S., \& Guttman, I. (1965). A new working formula for the split-half reliability model Educational and Psychological Measurement, 25(4), 963-967. https:// d o i . o r g / 10 . $11177 /$ 001316446502500402

Raufelder, D., \& Ringeisen, T. (2016). Selfperceived competence and test anxiety: The role of academic selfconcept and self-efficacy. Journal of Individual Differences, 37(3), 159-167. https://doi.org/10.1027/1614-0001/ a000202
Renner, K.-H., Heydasch, T., \& Ströhlein, G. (2012). Forschungsmethoden der Psychologie von der fragestellung zur Präsentation. Springer. https://doi.org/ 10.1007/978-3-531-93075-6_1

Richard, S., Dionne, C. E., \& Nouwen, A. (2011). Self-efficacy and health locus of control: Relationship to occupational disability among workers with back pain. Journal of Occupational Rehabilitation, 21(3), 421-430. https://doi.org/10.1007/ s10926-011-9285-5

Rovniak, L. S., Anderson, E. S., Winett, R. A., \& Stephens, R. S. (2002). Social cognitive determinants of physical activity in young adults: A prospective structural equation analysis. Annals of Behavioral Medicine, 24(2), 149-156. https:// d o i . o r g / 10 . 1207 / S15324796ABM2402_12

Rulon, P. J. (1939). A simplified procedure for determining the reliability of a test by split-halves. Harvard Educational Review, 9, 99-103.

Saraswati, N. K., \& Prihatsanti, U. (2017). Hubungan antara self-efficacy dengan intensi turnover pada karyawan PT. Indonesia Taroko Textile Purwakarta. Jurnal Empati, 6(1), 307-311. https:// ejournal3.undip.ac.id/index.php/ empati/article/view/15203

Schaubroeck, J., \& Merritt, D. E. (1997). Divergent effects of job control on coping with work stressors: The key role of selfefficacy. In Academy of Management Journal (Vol. 40, Issue 3, pp. 738-754). Academy of Management. https:// doi.org/10.2307/257061

Schecker, H. (2014). Überprüfung der Konsistenz von Itemgruppen mit Cronbachs á. OnlineZusatzmaterial zu Kapitel 28 des Handbuches. In Methoden in der naturwissenschaftsdidaktischen Forschung.

Scholz, U., Doña, B. G., Sud, S., \& Schwarzer, R. (2002). Is general self-efficacy a universal construct? Psychometric findings from 25 countries. European 
Journal of Psychological Assessment, 18(3), 242-251. https://doi.org/ $10.1027 / / 1015-5759.18 .3 .242$

Schwarzer, R. (2016). Health action process approach (HAPA) as a theoretical framework to understand behavior change. Actualidades En Psicología, 30(121), 119-130. https://doi.org/ 10.15517/ap.v30i121.23458

Schwarzer, R., Born, A., Iwawaki, S., Lee, Y. M., Saito, E., \& Yue, X. (1997). The assessment of optimistic self-beliefs: Comparison of the Chinese, Indonesian, Japanese, and Korean versions of the General Self-Ffficacy scale. Psychologia: An International Journal of Psychology in the Orient, 40(1), 1-13.

Schwarzer, R., \& Jerusalem, M. (1995). Generalized self-efficacy scale. In Measures in health psychology: A user's portfolio. Causal and control beliefs (pp. 35-37). Nfer-Nelson.

Sherer, M., Maddux, J. E., Mercandante, B., Prentice-Dunn, S., Jacobs, B., \& Rogers, R. W. (1982). The Self-Efficacy Scale: Construction and validation. Psychological Reports, 51(2), 663-671. h t tp s: / / doi.org/10.2466/ pr0.1982.51.2.663

Sijtsma, K. (2009). On the use, misuse, and the very limited usefulness of cronbach's alpa. Psychometrika, 74(1), 107-120. https://doi.org/10.1007/S11336-0089101-0

Sonnentag, S., \& Fritz, C. (2007). The Recovery Experience Questionnaire: Development and Validation of a Measure for Assessing Recuperation and Unwinding From Work. Journal of Occupational Health Psychology, 12(3), 204-221. https://doi.org/10.1037/10 76 8998.12.3.204

Sonnentag, S., Venz, L., \& Casper, A. (2017). Advances in recovery research: What have we learned? What should be done next? Journal of Occupational Health
Psychology, 22(3), 365-380. https:// doi.org/10.1037/ocp0000079

Syrek, C., Bauer-Emmel, C., \& Antoni, C. (2011). Entwicklung und validierung der Trierer Kurzskala zur Messung von Work-Life Balance (TKS-WLB). = Development and validation of the Trierer Scale to Measure Work-Life Balance (TKS-WLB). Diagnostica. https://doi.org/10.1026/ 0012-1924/a000044

Taheri, S., Lin, L., Austin, D., Young, T., \& Mignot, E. (2004). Short sleep duration is associated with reduced leptin, elevated ghrelin, and increased body mass index. PLoS Medicine, 1(3), e62. h t tps://doi.org / 10.1371 / journal.pmed.0010062

Van Den Berg, A. E., \& Custers, M. H. G. (2010). Gardening Promotes Neuroendocrine and Affective Restoration from Stress. Journal of Health Psychology, 16(1), 3-11. h t tps://doi .org / 10.1177 / 1359105310365577

Vollmann, M. \& Weber, H. (2011). Gesundheitspsychologie. In A. Schüt, M. Brand, H. Selg, \& S. Lautenbacher (Eds.), Psychologie - Eine einführung in ihre Grundlagen und Anwendungsfelder (4th ed.). Kohlhammer.

Weiber, R., \& Mühlhaus, D. (2014). Sturkturgleichungsmodellierung Eine anwendungsorientierte Einführung in die Kausalanalyse mit Hilfe von AMOS, SmartPLS und SPSS, 2. Auflage. Springer Gabler. https://doi.org/10.1007/978-3642-35012-2

Widarjono, A. (2015). Analisis multivariat terapan dengan Program SPSS, AMOS, dan SMARTPLS (2nd ed.). UPP STIM YKP.

Williams, R. H., \& Zimmerman, D. W. (1966). An extension of the rulon formula for test reliability: The case of correlated true and error components of scores. ETS Research Bulletin Series, 1966(2), i-8. https://doi.org/10.1002/j.23338504.1966.tb00702.x 
Zhang, C. Q., Zhang, R., Schwarzer, R., \& Hagger, M. S. (2019). A meta-analysis of the Health Action Process Approach. Health Psychology, 38(7), 623-637. https:// doi.org/10.1037/hea0000728

Received 10 September 2019 Revised 19 February 2020 Accepted 30 May 2020 
